\title{
Differences in perceptions of the living environment by respondent age
}

This article explores whether potential statistically significant differences in terms of respondents' demographic characteristics (i.e., age) can point to intergenerational differences in perceptions of the living environment. A quantitative methodology was used. Older respondents reported higher satisfaction, a stronger feeling of socioeconomic homogeneity of the neighbourhood, better neighbourly relations, and more positive opinions on the maintenance of the built environment than did younger respondents. In turn, younger respondents expressed a higher level of agreement about vandalism and physical and verbal attacks in the neighbourhood. These results were unexpected because previous studies showed significantly lower levels of agreement regarding satisfaction with the built environment and significantly higher levels of agreement about crime among older respondents than younger ones. They can be explained by the findings of many researchers, who established that the elderly generally still prefer to grow old at home - that is, in the environment they are familiar with, because they are often afraid that moving to an eldercare facility would inevitably cause them to lose their independence. Therefore, they tend to accept the environment where they live the way it is. On the other hand, the article shows that a series of statistically significant differences established indicates that the living environment, which has a strong impact on people's satisfaction and wellbeing, nonetheless does not offer the same quality of the built social infrastructure to all users (i.e., users with different demographic characteristics).

Keywords: social infrastructure, built environment, demographic characteristics, older respondents, Slovenia 


\section{Introduction}

Quality of life, which is a dominant concept around the globe today, can be difficult to imagine without the concept of the quality of the urban environment, the design of which tends to be increasingly human-oriented (Temeljotov Salaj \& Petrič, 2009). As a term, the quality of the urban environment is conceived as an integral whole that encompasses the social perceptions of this environment (i.e., the neighbourhood) and the quality of the built living environment itself, which should satisfy all users. According to Adriaanse (2007), there are three "iron variables" influencing the quality of the urban environment: age, residential community characteristics, and physical characteristics of the built environment. It focuses on whether there are any statistically significant differences by respondent age in perceptions of residential community characteristics (general satisfaction, socioeconomic homogeneity, neighbourly relations, crime rate, fear and discomfort, and help among neighbours) and the characteristics of the built environment (development, maintenance, and cleanliness). The article also explores whether there are any statistically significant differences among respondents that might indicate significant intergenerational differences in perceptions of the built environment or, more broadly, perceptions of the built social infrastructure they live in.

The degree of development of a place influences its users' feeling of satisfaction and needs in that place (Missimer et al., 2017; Sierra et al., 2017, 2018). Many authors, including Baumeister and Leary (1995) and Engle and Altschuld (2014), highlight the fact that needs must be first taken into account because they influence thinking, emotions, and behaviour under any conditions; if they are not satisfied, negative effects must be taken into account. When needs are not satisfied, their objective importance should increase or decrease. Researchers have also stressed that attention should be paid to everyone's common needs. According to Kulbickienè (2004), needs reflect residents' orientations and choices. Therefore, an analysis of social infrastructure needs is conceived as an evaluation of the demand for services and facilities (Weber et al., 2016). A definition of needs refers to describing "problems" of the target population and possible solutions (Vaznoniene \& Pakeltiene, 2017). Hence, an analysis of needs focuses on the future, or on what must be done rather that what has been done (Vaznoniené \& Pakeltiené, 2017).

This article understands built social infrastructure as a structure that has been built based on users' needs and that is measured by the level of user satisfaction (wellbeing). Built social infrastructure is a predominant factor that ensures that basic human needs are satisfied (Frolova et al., 2016). If a current social infrastructure meets a community's needs and expectations, its residents achieve a higher quality of life. If social infrastructure fails to satisfy residents' needs or create choice, special social and economic issues develop and affect the community's wellbeing (Vaznoniené, 2015). Wellbeing reflects the quality of life. There is a lack of studies exploring the relationship between the factors influencing a population's wellbeing and the level of social infrastructure development within a community (or country). A similar study was conducted by Popov (2017), who examined the relationship between transport infrastructure and wellbeing factors using a correlation analysis based on data provided by the Latvian Statistical Office. Popov's study opens a wide area for further detailed research, and it also encouraged the author of this article to conduct a detailed analysis of individual factors within a community (in the sense of users' perceptions) and the built environment by basic demographic characteristics of the respondents. As the input demographic factor, the author distinguishes between three age groups or generations based on the classification by Miloševič Arnold (2003): younger than thirty-five, thirty-five to sixty-five, and older than sixty-five. The elderly are treated as a single group above sixty-five. This age limit (i.e., sixty-five) is also used by the Slovenian Statistical Office.

\section{Perceptions of the built environment}

Erdogan et al. (2008) argue that perceived living conditions directly influence overall housing satisfaction and that they are connected with satisfaction with the physical environment, social relations, the operation of local authorities, and perceived quality of the environment and facilities. Residents' opinions about their neighbourhood provide important insights into this issue. According to Adriaanse (2007), these opinions shed light on the aspects that have a greater impact on overall residential environment satisfaction. To some extent, residential environments can be defined through objective criteria, such as the period of construction, architectural style, spatial structure, the quantity of green areas, and geographical location. With regard to neighbourhood satisfaction, Sirgy and Cornwell (2002) divide various neighbourhood attributes affecting satisfaction into physical features (e.g., upkeep of homes and yards, landscape and street lighting, crowding and noise level, nearness to facilities, and quality of the environment), social features (social interaction with neighbours, ties with people in the community, outdoor play space, crime, and sense of privacy at home), and economic features (home value in the neighbourhood, cost of living, socioeconomic status of the neighbourhood, and neighbourhood improvement). Several other authors have also established that housing satisfaction is influenced by a wide range of objectively and subjectively perceived 
conditions (Theodori, 2001; Grum \& Temeljotov Salaj, 2013; Grum \& Kobal Grum, 2015). Urban planners ascribe great importance to social issues and quality of life, which suggests that housing is a social issue that entails not only its construction and environment, but also satisfaction with the quality of its environment (Sam et al., 2012). Architects agree with urban planners that this consequently impacts residents' quality of life and psychosocial aspects (Mohit et al., 2010). Researchers argue that residential satisfaction reflects the satisfaction and happiness in the residential area or neighbourhood (Sam et al., 2012). This includes social and neighbourly relations, social activities, social facilities, scenery, and utilities (Sam et al., 2012). In addition to satisfaction, socioeconomic homogeneity, and the related stability of the neighbourhood, a sense of safety is also important; many studies link this to the crime rate in the environment (Newman, 1972, Meško, 2001; Grum, 2017). According to Meško (2001), spatial design should provide a structure that discourages crime - that is, the external features of the environment should be based on properties that show that the environment is under control, and as such it should create a sense of safety in people. Such a neighbourhood stimulates greater concern for the environment, more contact with neighbours (good neighbourly relations), and more help among neighbours, and its residents are also more satisfied with their homes (Grum, 2017). Newman (1972) combines these factors into territoriality (a sense of belonging to the neighbourhood), natural surveillance (perception of socioeconomic homogeneity, and the presence of police, security services, and firefighters), image and milieu (maintenance, parks, parking areas, and walking trails), and the environment (the development of built social infrastructure).

With regard to respondent age, many studies show that the elderly want to stay in their homes (i.e., the environment they are familiar with) as long as they can and to retain their independence and autonomy as long as possible (Rojo et al., 2001; Sabia, 2008; Costa Font et al., 2009; Wiles et al., 2009). Roy et al. (2018) report that relocations among the elderly are significantly influenced by factors connected with the built environment and factors connected with the social, psychological, psychosocial, spatiotemporal, and decision-making context. In general, the elderly still prefer to grow old at home (Harper \& Bayer, 2000; Greenwald et al., 2003; Secker et al., 2003; Wylde, 2008), often because they are afraid that moving to an eldercare facility would inevitably cause them to lose their independence (Parry et al., 2004; Imamoglu, 2007). The space that refers to the elderly's relationship with their living environment, as a symbolic representation of "home" as one's independence (Parry et al., 2004), can form the basis for further conceptual improvements (Kemp et al., 2012). However, many studies show that a poorly maintained built environment can prevent physical activity among the elderly
(Balfour \& Kaplan, 2002; Strath et al., 2007; Mendes de Leon et al., 2009; Gallagher et al., 2010). Therefore, the elderly are especially responsive to specific aspects of the built environment (Grum, 2017). Many studies indicate the effect of certain demographic factors, such as residents' age, on the degree of fear expressed and the interaction between the respondents' social structure and their experience of fear (Ferguson \& Mindel, 2007). A sense of community can help people have greater faith in their own abilities, which reduces their feeling that they might be victimized and their fear (Meško et al., 2012). On the other hand, younger participants can perceive the built environment and relationships within it differently. Uršič (2005) studied Ljubljana’s Sava housing development (Sln. Savsko naselje) to establish whether factors such as the neighbourhood's age, poor maintenance, and the resulting poorer quality of life in the neighbourhood cause certain population groups to move elsewhere and the lack of social homogeneity and stability to increase. He determined that over a fifth of the residents planned to move in the near future, and that these primarily involved younger residents (i.e., below forty).

The elements of the built environment affect user behaviour. If the living environment is well maintained and clean, it is expected that individual residential buildings within it are also well maintained and in harmony with the neighbourhood and the built environment they are located in (Grum, 2017). However, the environment usually influences the level of expected (or required) maintenance of buildings (well-maintained infrastructure usually requires well-maintained accommodation capacities, otherwise the feel of the neighbourhood is not uniform and users' wellbeing is poorer; Grum, 2017). The summarised findings of the literature review provided guidance for designing the questionnaire.

\section{Methodology}

Studies of the living environment have been conducted for a long time, but, as already established by Smrke et al. (2018), no systematic overview of questionnaires used in these kinds of studies has been published in Slovenia to date. Smrke et al. (2018) argue that researchers should lean more towards using questionnaires already developed, but they agree that there are not many questionnaires in this area of research with established validity. Hence, the methodology used in this article is based on a quantitative approach: specifically, a questionnaire that was designed in line with findings from the literature (Grum \& Temeljotov Salaj, 2011). The research questions that arise in studying the quality of the urban living environment or the degree of user satisfaction and needs, now largely rely on multidisciplinary research approaches, which in 


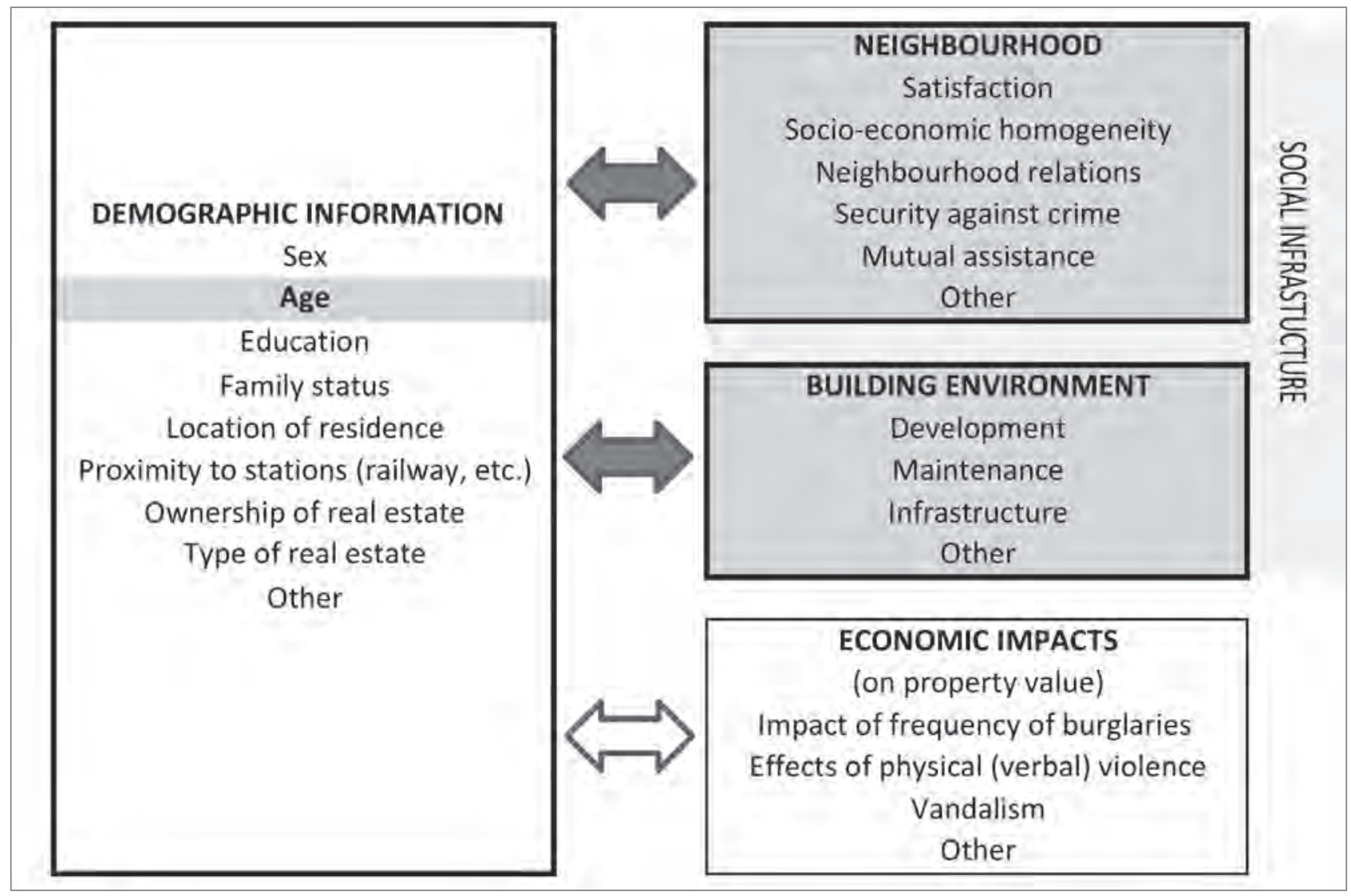

Figure 1: Identified factors, among which the correlation between the demographic data (age), the neighbourhood, and the built environment was of main interest in the remainder of the study (illustration: author).

and of itself repeatedly raises new questions. Thus, unexplored research areas are opening that high-quality measurement instruments do not always keep pace with. However, certain contradictory findings in studying living environment satisfaction and numerous evaluation-related questions that remain open are not merely the result of inadequate methodological approaches. The author agrees that the method of measuring living environment satisfaction is important in empirical analyses, especially in new studies (like the one presented here), which may provide important answers to research questions, either in terms of eliminating any such influences on the results obtained or confirming repeatable and tested methodology or measurement instruments.

The cognitive objectives of the study are descriptive (i.e., a description of features and current state) and explanatory (i.e., identifying and explaining interdependencies). The results of the current literature review above form the operationalization basis. The study was designed in two stages (Grum \& Temeljotov Salaj, 2011). In the first stage, a questionnaire was developed and the suitability of its metric characteristics was established. To this end, a pilot study was performed on an appropriate sample $(n=55)$. The data were collected through an online survey conducted in 2018. A structured and closedtype questionnaire was used. SPSS software was used to process the data collected. Respondents provided their answers using a five-point Likert scale ( $1=$ completely disagree, $5=$ completely agree). The questionnaire contained twenty-six questions. An exploratory factor analysis was conducted, which means the correlations between variables were studied by identifying a set of latent variables (fewer than measured variables) underlying the battery of measured variables. Orthogonal rotation was applied to identify theoretically important factors and the simplest possible factor structure. Key concepts cannot be directly measured; instead, they are measured indirectly using indicators of that which is supposed to be measured. In line with literature, several directly measurable variables that serve as indicators of the concept (construct) to be measured are selected, after which it is established whether the relationships between the selected observed variables can be explained with the proposed latent variable or whether a more complex correlation structure may have to be built. The goal is to establish whether the correlations between observed variables can be explained with a smaller number of directly observed variables or factors. The factor analysis thus identified four factors that explain over $63.88 \%$ of variation, which is above the required minimum of $60 \%$ (Bastič, 2006). The factors identified overlap with factors that were grouped in the questionnaire. Questions related to social structure variables and describing the neighbourhood features as perceived by residents (e.g., satisfaction, 
Table 1: The results of variance analysis

\begin{tabular}{|c|c|c|c|c|c|c|}
\hline Variable & & SS & df & MS & $\mathrm{F}$ & $p$ \\
\hline Infrastructure (police, fire brigade, etc.) & $*$ & 12.26 & 4 & 3.064 & 2.473 & 0.043 \\
\hline Home satisfaction & & 1.54 & 4 & 0.385 & 0.370 & 0.830 \\
\hline Socioeconomic homogeneity & & 2.95 & 4 & 0.737 & 1.088 & 0.362 \\
\hline Neighbourly relations & * & 6.46 & 4 & 1.615 & 2.285 & 0.050 \\
\hline Frequency of crime & * & 31.30 & 4 & 7.825 & 2.489 & 0.042 \\
\hline General feeling of fear & & 10.12 & 4 & 2.530 & 1.470 & 0.209 \\
\hline Mutual help & & 1.42 & 4 & 0.355 & 0.465 & 0.762 \\
\hline Development of built environment & * & 13.39 & 4 & 3.348 & 3.055 & 0.016 \\
\hline Maintenance of built environment & & 4.44 & 4 & 1.109 & 1.402 & 0.232 \\
\hline
\end{tabular}

*Statistically significant difference $(p<0.05)$

**Statistically significant difference $(p<0.01)$

***Statistically significant difference $(p<0.001)$

socioeconomic homogeneity, neighbourly relations, crime safety, mutual help, etc.) were heavily saturated with the first factor (18.15\%). Questions referring to economic effects on real-estate value (e.g., impact of frequent break-ins, physical or verbal violence, vandalism, etc.) were heavily saturated with the second factor (17.07\%). Questions related to the built environment (e.g., infrastructure development, maintenance, etc.) were heavily saturated with the third factor (14.97\%). The factor analysis placed the variable "neighbourhood cleanliness" under a separate factor (14.67\%), but strong correlations with the built environment variables (e.g., the negative correlation between good maintenance and poor cleanliness was -0.55 ) were evident, which is why this variable was theoretically categorized under built environment variables and is not addressed below. Thus, this article addresses three factors key to the study. The factors identified are shown in Figure 1, which also highlights the main interests of the study and the subject of further analyses.

The appropriateness of using a factor analysis was tested with Bartlett's Test of Sphericity (BT $=759.61)$, whose high statistical reliability implied that it was possible to interpret the factors identified (Fulgosi, 1984). A high value of this measure supports the use of this method (Bastič, 2006). In addition to Bartlett's test, the Kaiser-Meyer-Olkin Test $(\mathrm{KMO}=0.563)$ was also applied. Using factor analysis makes sense if the value of this measure is high - that is, over 0.5 (Bastič, 2006). The reliability of the questionnaire was tested using Cronbach's alpha (a measure of internal consistency). The value of alpha varies from 0 to 1 and the reliability is acceptable if the coefficient is greater than 0.60 (Bastič, 2006). Its value for the entire questionnaire was 0.603 . Cronbach's alpha for the first social infrastructure factor identified (i.e., neighbourhood) was 0.64 , for the second social infrastructure factor identified (built environment) it was 0.66 , and for the third factor identified (economic effects) it was 0.62 .
The second stage comprised the central cross-sectional study. The questionnaire designed as part of the pilot study was used, applying snowball sampling for collecting data (Lobe, 2006). With this sampling technique, personal contacts are used to build the research sample group. A smaller sample of individuals is first selected; they complete the questionnaire and at the same time invite their acquaintances to do the same (Klinc et al., 2010). Each subsequent respondent is expected to provide a few more. The advantage of this sampling technique primarily lies in the fact that the original sample is expanded quickly, which in turn depends exclusively on the selection of the initial population. This is also its weakness, because after the initial selection of the sample the researcher no longer has any control over it. The survey included 729 respondents, of whom 250 were younger than thirty-five (34.29\%), 362 were between thirty-five and sixty-five (49.66\%), and 117 were older than sixty-five (16.05\%). In terms of employment, twelve respondents were unemployed $(1.65 \%), 188$ were students (25.79\%), 431 were employed (59.12\%), and ninety-eight were retired (13.4\%). Respondents were fairly evenly represented in terms of sex: there were 376 women $(51.60 \%)$ and 353 men (48.40\%).

The focus was on which statistically significant differences by respondent age refer to the neighbourhood itself (the community) and which to the built environment (i.e., built social infrastructure).

\section{Results}

Based on a strong correlation between age and employment status (Pearson's correlation coefficient $r=0.57$ ), the data were first analysed by age and employment using a multivariate analysis of variance (MANOVA; see Table 1). This made it possible to examine whether such analysis showed different statistically 
Table 2: ANOVA results by respondent age and built social infrastructure.

\begin{tabular}{lllllll}
\hline Variable & & SS & df & MS & $F$ & $p$ \\
\hline Infrastructure (police, fire brigade, etc.) & $*$ & 7.37 & 2 & 3.687 & 2.875 & 0.050 \\
\hline Home satisfaction & $* *$ & 14.16 & 2 & 7.081 & 6.805 & 0.001 \\
\hline Socioeconomic homogeneity & $* *$ & 9.51 & 2 & 4.757 & 7.017 & 0.001 \\
\hline Neighbourly relations & $* * *$ & 11.23 & 2 & 5.615 & 7.946 & 0.000 \\
\hline Frequency of crime & & 0.13 & 2 & 0.063 & 0.020 & 0.980 \\
\hline General feeling of fear & & 0.90 & 2 & 0.449 & 0.261 & 0.770 \\
\hline Mutual help & $*$ & 3.62 & 2 & 1.809 & 2.366 & 0.095 \\
\hline Development of built environment & $* * *$ & 12.69 & 2 & 6.347 & 8.025 & 0.000 \\
\hline Maintenance of built environment & & 9.19 & 2 & 4.596 & 4.193 & 0.015 \\
\hline
\end{tabular}

*Statistically significant difference $(p<0.05)$

**Statistically significant difference $(p<0.01)$

***Statistically significant difference $(p<0.001)$

significant differences in the observed variables than the ones obtained through a one-way analysis of variance (ANOVA). This would indicate that employment had a significant impact on the results.

Statistically significant differences $(p<0.01)$ by age and employment status were shown in relation to the importance of infrastructure development (connected with the presence of police and fire stations, security services, etc.), the neighbourhood's socioeconomic homogeneity, neighbourly relations, the frequency of crime (break-ins, thefts, vandalism, and physical and verbal attacks), and the development of the built environment. The results showed an equal distribution of statistically significant differences between the two factors observed: two within the first factor (neighbourhood) and two within the second one (built environment). The data were also analysed by age using a one-sided analysis of variance (ANOVA), the results of which are presented in Table 2.

Statistically significant differences $(p<0.01)$ by age and general features of the built environment were shown in relation to the importance of infrastructure development connected with the presence of the police and fire stations, security services, and so on, home satisfaction, the neighbourhood's socioeconomic homogeneity, neighbourly relations, the development of the built environment, and its maintenance. The results showed an uneven distribution of statistically significant differences between the two factors observed: four within the first factor (neighbourhood) and only two within the second one (built environment).

Table 3 shows the average values of respondent agreement in terms of the statistically significant differences presented in Tables 1 and 2. The results show a fairly even distribution of statistically significant differences between the two factors observed. Based on this, it can be concluded that employment itself does not have a significant impact on the results sought, even though it correlates with age. Thus, four statistically significant differences were established within the first factor (neighbourhood) and three within the second one (built environment). The statistically significant differences within the two factors observed thus indicate that the most important factor among those identified in the factor analysis is neighbourhood. inside which statistically significant differences can be observed with the majority of the variables observed.

Younger respondents showed a significantly higher level of agreement regarding the proximity of infrastructure (i.e. the police, firefighters, and security services) than older respondents $(M=3.423)$. This means that older respondents perceive this type of infrastructure as being further from their home than do younger respondents. With regard to satisfaction with their current home, older respondents showed a significantly higher level of agreement than younger respondents $(M=$ 4.058). In terms of feeling that their neighbourhood is socioeconomically homogenous and consequently stable. older respondents expressed a significantly higher level of agreement than younger ones $(M=3.758)$. Older respondents also showed a markedly higher level of agreement about good neighbourly relations $(M=3.717)$. The results thus demonstrate that older respondents show strong satisfaction with their living environment. The importance of this was also confirmed by Ramovš (2000), who established that interpersonal relations are just as important as financial security. According to Kobal Grum and Grum (2018), exclusion from the social environment causes loneliness. isolation, a feeling of insecurity, and loss of a sense of purpose in life. and therefore it is crucial to support the elderly in their integration into the social environment. The results can be partially explained through the findings of Filipovič et al. (2005), who established that in Slovenia the 
Table 3: Average values of respondent agreement in terms of home satisfaction and age.

\begin{tabular}{|c|c|c|c|c|c|c|c|}
\hline \multicolumn{2}{|l|}{ Variable } & \multirow{2}{*}{$\begin{array}{l}\text { Number of } \\
\text { participants } \\
\mathrm{N}\end{array}$} & \multirow{2}{*}{$\begin{array}{l}\text { Medium } \\
\mathrm{M}\end{array}$} & \multirow{2}{*}{$\begin{array}{l}\text { Std. diviation } \\
\text { SD }\end{array}$} & \multirow{2}{*}{$\begin{array}{l}\text { Std. error } \\
\text { medium SEM }\end{array}$} & \multicolumn{2}{|c|}{ Confidence interval average } \\
\hline & & & & & & Lower limit & Upper limit \\
\hline \multirow{3}{*}{$\begin{array}{l}\text { Infrastructure (police, fire } \\
\text { brigade, etc.) }\end{array}$} & 1 & 258 & 3.423 & 1.038 & 0.065 & 3.295 & 0.360 \\
\hline & 2 & 376 & 2.926 & 1.155 & 0.060 & 2.808 & 3.043 \\
\hline & 3 & 89 & 3.098 & 1.247 & 0.131 & 2.625 & 3.150 \\
\hline \multirow{3}{*}{ Home satisfaction } & 1 & 260 & 3.842 & 0.889 & 0.055 & 3.734 & 3.951 \\
\hline & 2 & 380 & 3.918 & 1.107 & 0.057 & 3.807 & 4.030 \\
\hline & 3 & 85 & 4.059 & 1.062 & 0.115 & 3.830 & 4.288 \\
\hline \multirow{3}{*}{$\begin{array}{l}\text { Socioeconomic } \\
\text { homogeneity }\end{array}$} & 1 & 258 & 3.636 & 0.778 & 0.048 & 3.540 & 3.731 \\
\hline & 2 & 378 & 3.661 & 0.863 & 0.044 & 3.574 & 3.749 \\
\hline & 3 & 87 & 3.759 & 0.876 & 0.094 & 3.572 & 3.945 \\
\hline \multirow{3}{*}{ Neighbourly relations } & 1 & 260 & 3.592 & 0.898 & 0.056 & 3.483 & 3.702 \\
\hline & 2 & 380 & 3.663 & 0.833 & 0.043 & 3.579 & 3.747 \\
\hline & 3 & 85 & 3.718 & 0.781 & 0.085 & 3.549 & 3.886 \\
\hline \multirow{3}{*}{ Frequency of crime } & 1 & 260 & 2.988 & 1.671 & 0.104 & 2.784 & 3.192 \\
\hline & 2 & 378 & 2.854 & 1.883 & 0.097 & 2.664 & 3.045 \\
\hline & 3 & 87 & 2.241 & 1.635 & 0.175 & 1.893 & 2.590 \\
\hline \multirow{3}{*}{$\begin{array}{l}\text { Development of built } \\
\text { environment }\end{array}$} & 1 & 258 & 3.372 & 1.044 & 0.065 & 3.244 & 3.500 \\
\hline & 2 & 380 & 3.258 & 1.081 & 0.055 & 3.149 & 3.367 \\
\hline & 3 & 87 & 3.299 & 0.966 & 0.104 & 3.093 & 3.505 \\
\hline \multirow{3}{*}{$\begin{array}{l}\text { Maintenance of built } \\
\text { environment }\end{array}$} & 1 & 258 & 3.457 & 0.851 & 0.053 & 3.353 & 3.562 \\
\hline & 2 & 378 & 3.402 & 0.914 & 0.047 & 3.310 & 3.495 \\
\hline & 3 & 87 & 3.586 & 0.909 & 0.097 & 3.392 & 3.780 \\
\hline
\end{tabular}

Note: 1 - younger than 35, 2 - younger than 65, 3 - older than 65 .

importance of neighbours in all types of support increased with respondent age. However, it is interesting that with regard to crime in the neighbourhood older respondents showed a higher level of agreement about break-ins and theft (e.g., stolen purses or wallets on buses; $M=3.717$ ), whereas younger respondents expressed a higher level of agreement about vandalism and physical and verbal attacks $(M=2.988)$. This can be confirmed by the findings of Meško et al. (2012), who reported that young people are the least afraid of crime, even though they are the ones that are most frequently victimized. A sense of community may help people develop greater faith in their own abilities, which reduces their feeling that they might be victimized and their fear (Meško et al., 2012). It is also interesting that the highest level of agreement about the development of the built environment (facilities, parking areas, parks, walking trails, etc.) was evident among young respondents $(M=$ $3.372)$, followed by the elderly $(M=3.298)$. Middle-aged respondents showed the lowest level of agreement $(M=3.257)$, which means that the middle-aged generation is the least satisfied with the development of the built environment. This can also be explained by the results of the study conducted by Trček (2005), who performed a detailed analysis of factors such as age, building and housing quality, neighbourly relations, and future respondent preferences. With regard to living environment dissatisfaction, he established that the greatest problem was parking areas (dissatisfaction expressed by $60.2 \%$ of respondents), whereas respondents expressed a high level of satisfaction with neighbourhood safety $(52.7 \%)$ and neighbourly relations (56.9\%). Parking areas probably concern the middle-aged or active working generation significantly more than the elderly, who are considerably less mobile on a daily basis. However, older respondents showed a significantly higher level of agreement about the maintenance of the building environment (derelict buildings, dark and unlighted passageways and walking trails, unmaintained parks, fallen trees, etc.) than younger ones $(M=3.586)$, which is surprising. The elderly 
were expected to show significantly lower levels of agreement, especially about the maintenance of the built environment. On the contrary, the results showed that, compared to younger respondents, in general the elderly are considerably more satisfied with both the characteristics of the residential community and the physical characteristics of the built environment. These results can be explained by the findings of many researchers, who established that in general the elderly still prefer to grow old at home or in the environment they are familiar with and accept because they are often afraid that moving to an eldercare facility would inevitably cause them to lose their independence. Kobal Grum and Grum (2018) highlight the fact that neighbour networks constitute an important part of people's personal network. Hence, it can be concluded that satisfaction with one's home or residential factors referring to a potential home or living environment (neighbourhood) also requires a high or optimal level of emotional wellbeing (Kobal Grum \& Grum, 2018). In addition, the results obtained can also be compared to the results of exploring a relatively new phenomenon in home-related psychological factors: attachment or place attachment (Khozaei et al., 2012). Thus, attachment, as a well-known and fairly well-studied phenomenon in psychology (Howe, 2011), is acquiring a new dimension through studying users' attitude towards places. It seems that people that find it important in what infrastructural environment they live or would like to live also exhibit constructive place attachment through higher subjective emotional wellbeing (Florek, 2011). Such findings can have a key impact on creating a successful intergenerational housing policy. Population aging is not a process that societies should prevent, but a process that should be understood as a result and consequence of planned or desired processes and one that also requires appropriate adaptation of social institutions and services (Kerbler, 2011). A high-quality living environment is accompanied by good spatial relations only when these also make it possible to fulfil as many needs of residents as possible (Zapušek \& Kučan. 2009). However, these interests or needs change with age and social position.

\section{Conclusion}

Different types of neighbourhoods have different characteristics and can thus reflect different problems among their users. This article proceeds from the three variables established by Adriaanse (2007): age, residential community characteristics, and physical characteristics of the built environment. It thus focuses on determining whether there are any statistically significant differences by respondent age in relation to residential community characteristics (general satisfaction, socioeconomic homogeneity, neighbourly relations, crime rate, feeling of fear and discomfort, and help among neighbours) and the built environment (development, maintenance, and cleanliness). The article also explores whether any statistically significant differences perceived by respondents can point to intergenerational differences in the perception of the living environment or, more broadly, the perception of the built social infrastructure they live in.

The elderly were expected to show significantly lower levels of agreement, especially about the maintenance of the built environment. On the contrary, the results showed that, compared to younger respondents, in general the elderly are considerably more satisfied with both the characteristics of the residential community and the physical characteristics of the built environment. These results can be explained by the findings of many researchers, who established that in general the elderly still prefer to grow old at home or in the environment they are familiar with and accept because they are often afraid that that moving to an eldercare facility would inevitably cause them to lose their independence. Within this context, they uncritically "defend" their living environment regardless of their deficiencies because, no longer being economically involved in the society (retired or having limited income), they no longer feel socially active in the sense of having any major influence on remedying these deficiencies. As established by Pain (2000), researchers have lately been increasingly viewing age as a cultural category and no longer a chronological one, which means they focus on the special features of the circumstances and lifestyles of people at various stages of life.

The results of this study indicate a series of statistically significant differences by respondent age (intergenerational gaps). The statistically significant differences within the factors observed (the neighbourhood and the built environment) show that among all the factors identified in the factor analysis neighbourhood is the most important. inside which statistically significant differences can be observed with the majority of the variables observed. The study shows that living environment has a strong impact on residential satisfaction and wellbeing. In line with many other authors (e.g., Adriaanse, 2007; Kobal Grum \& Grum, 2018), it can be concluded that most urban planners and designers have not made any breakthrough in designing neighbourhoods, in which people of all generations should live comfortably and use residential social infrastructure of the highest possible quality regardless of age differences. According to Sendi (2005), modern times require a modern perspective on planning residential areas. Planning that does not take account of the opinions and desires of current or potential residents is no longer acceptable, no longer works, and no longer leads to optimal land use. Both in spatial planning - where the central question is still how to ensure appropriate land use that will accord with the goals and orientations of social development and where all actors appear as equal partners (Ravbar, 2007) - and in planning residential 
areas, the central question that remains is how to utilize residential use to achieve optimal land use. Optimal land use can be understood as an expanded definition of most economical land use, one that is also supported by people's expectations, desires, aspirations. and so on. These findings are primarily important for evaluating the quality of life, which is a dominant concept around the world today and is difficult to imagine without the concept of quality of the urban environment. The quality of measurement instruments should be improved in future studies in the sense of using or translating available foreign-language questionnaires. In addition, the findings established show that understanding the observed differences by the demographic characteristics of spatial users is key for designing a sustainable housing policy.

Bojan Grum

Nova univerza, Evropska pravna fakulteta, Ljubljana, Slovenia e-mail: bgrum@siol.net

\section{References}

Adriaanse, C. C. M. (2007) Measuring residential satisfaction: a residential environmental satisfaction scale (RESS). Journal Housing Built Environment, 22, pp. 287-304. DOI: 10.1007/s10901-007-9082-9

Balfour, J. L. \& Kaplan, G. J. (2002) Neighborhood environment and loss of physical function in older adults: Evidence from the Alameda county study. American Journal of Epidemiology, 155(6), pp. 507-515. DOI: 10.1093/aje/155.6.507

Bastič, M. (2006) Metode raziskovanja. Maribor, Univerza v Mariboru, Ekonomsko poslovna fakulteta Maribor.

Baumeister, R. F. \& Leary, M. R. (1995) The need to belong: Desire for interpersonal attachments as a fundamental human motivation. Psychological Bulletin, 117(3), pp. 497-529. DOI: 10.1037//0033-2909.117.3.497

Costa-Font, J., Mascarilla-Miró, O. \& Elvira, D. (2009) Ageing in place? An examination of elderly people housing preferences in Spain. Urban studies, 46(2), pp. 295-316. DOI: 10.1177/0042098008099356

Engle, M. \& Altschuld, J. W. (2014) Needs assessment: The perspective from the public sector. In: Altschuld, J.W. \& R. Watkins (eds.) Needs assessment: Trends and a view toward the future. New directions for Evaluation, pp. 33-45. Hoboken, NJ. Wiley. DOI: 10.1002/ev.20101

Erdogan, N., Akyol, A., Ataman, B. \& Domkeci, V. (2008) Comparison of urban housing satisfaction in modern and traditional neighborhoods in Edirne, Turkey. Social Indicators Research, 81(1), pp. 127-148. DOI: 10.1007/s11205-006-0018-7

Ferguson, K. M. \& Mindel, C. H. (2007) Modeling fear of crime in Dallas neighborhoods: A Test of social capital theory. Crime Delinquency, 53(2), pp. 658-679. DOI: $10.1177 / 0011128705285039$

Filipovič Hrast, M., Kogovšek, T. \& Hlebec, V. (2005) Starostniki in njihova vpetost v sosedska omrežja. Družboslovne razprave, 49/50, pp. 205-221.

Florek, M. (2011) No place like home: Perspectives on place attachment and impacts on city management. Journal of Town \& City Management, 1(4), pp. 346-354.

Frolova, E.V., Vinichenko, M. V., Kirillov, A. V., Rogach, O. V., \& Kabanova E. E. (2016) Development of social infrastructure in the management practice of local authorities: Rends and factors. International Journal of Environmental \$ Science Education, 11(15), pp. 7421-7430.
Fulgosi, A. (1984) Faktorska analiza. Zagreb, Filozofski fakultet v Zagrebu.

Gallagher, N. A., Gretebeck, K. A, Robinson, J. C, Torres, E. R., Murphy, S. L. \& Martyn, K. K. (2010) Neighborhood factors relevant for walking in older, urban, African American adults. Journal of Aging and Physical Activity, 18(1), pp. 99-115. DOI: 10.1123/japa.18.1.99

Greenwald, M., Barrett, L. L., Ginzler, E., Copeland, A., Kochera, A. \& Straight, A. (2003) These four walls. Americans 45+ talk about home and community. AARP, 601 E Street, NW Washington, DC 20049. Available at: http://assets.aarp.org/rgcenter/il/four_walls.pdf (accessed 20 Oct. 2018).

Grum, B. (2017) Impact of facilities maintenance on user satisfaction. Facilities, 35(7-8), pp. 405-421. DOI: 10.1108/f-03-2016-0034

Grum, B. \& Kobal Grum, D. (2015) A model of real estate and psychological factors in decision-making to buy real estate. Urbani izziv, 26(1), pp. 82-91. DOI: 10.5379/urbani-izziv-en-2015-26-01-002

Grum, B. \& Temeljotov Salaj, A. (2011) Vloga lastnih in zunanjih dejavnikov pri konstrukciji vprašalnika za merjenje pričakovanj potencialnih pridobiteljev nepremičninskih pravic. Anthropos, 43 (1-2), pp. 257275. DOI: 10.5379/urbani-izziv-2010-21-02-004

Grum, B. \& Temeljotov Salaj, A. (2013) The comparison of expressed satisfaction and expectations of potential real estate buyers in Slovenia and Japan. Facilities, 31(1-2), pp. 6-23. DOI: 10.1108/02632771311292482

Harper, L. \& Bayer, A. H. (2000) Fixing to stay: A national survey of housing and home modification issues. Washington, DC, AARP.

Howe, D. (2011) Attachment across the lifecourse. London, Palgrave.

Imamoglu, C. (2007) Assisted living as a new place schema. A comparison with homes and nursing homes. Environment and Behavior, 39, pp. 246-268. DOI: 10.1177/0013916506289977

Kemp, C. L., Ball, M. M., Hollingsworth, C. \& Perkins, M. M. (2012) Strangers and friends: residents' social careers in assisted living. Pychological Sciences and Social Sciences, 67, pp. 491-502. DOI: 10.1093/geronb/gbs043

Kerbler, B. (2011) Prilagajanje grajenega bivalnega okolja za potrebe starejših ljudi. Geodetski vestnik, 55(1), pp. 57-69. DOI: 10.15292/geodetski-vestnik.2011.01.057-069

Khozaei, F., Ramayah, T., Hassan, A. S. \& Surienty, L. (2012) Sense of attachment to place and fulfilled preferences, the mediating role of housing satisfaction. Property Management, 30(3), pp. 292-310. DOI: 10.1108/02637471211233945

Klinc, R., Turk, Ž. \& Dolenc, M. (2010) Raziskava o rabi informacijskokomunikacijskih tehnologij v Slovenski gradbeni industriji. Gradbeni vestnik, 59, pp. 269-276.

Kobal Grum, D. \& Grum, B. (2018) The association between pro-environmental behaviour nad subjective well-being. In: Grum, B. (eds.) Book of proceedings, 3rd Conference of Interdisciplinary Research on Real Estate (CIRRE), pp. 43-53. Ljubljana, Institute of Real Estate Studies.

Kulbickienè, L. (2004) Lietuvos gyventojų kultūriniai poreikiai: kultūros istaigu vertinimas ir lankymas. Sociologija. Mintis ir veiksmas, 8(2), pp. 64-71.

Lobe, B. (2006) Mixing qualitative and quantitative methods in the environment of new information-communication technologies. Ljubljana, Fakulteta za družbene vede.

Mendes De Leon, C. F, Cagney, K. A., Bienias, J. L, Barnes, L.L., Skarupski, K.A., Scherr, P.A. \& Evans, D.A. (2009) Neighborhood, social cohesion and disorder in relation to walking in community-dwelling older adults: A multilevel analysis. Journal of Aging and Health, 21(1), pp. 155-171. DOI: $10.1177 / 0898264308328650$ 
Meško, G. (2001) Kriminala percepcija z načrtovanjem in oblikovanjem okolja. Socialna pedagogika, 5(4), pp. 445-468.

Meško, G., Šifrer, J. \& Vošnjak, L. (2012) Strah pred kriminaliteto v mestih in vaških okoljih v Sloveniji. Varstvoslovje, 14(3), pp. 259-276.

Miloševič Arnold, V. (2003) Komunikacija med zaposlenimi in svojci stanovalcev socialnih domov. In: Zbornik predavanj. 14. strokovno srečanje Zveze društev medicinskih sester in zdravstvenih tehnikov Slovenije, Terme Zreče, 21. in 22. oktober 2003, pp. 43-49). Zreče, Zbornica zdravstvene nege Slovenije - Zveza društev medicinskih sester in zdravstvenih tehnikov Slovenije.

Missimer, M., Robert, K.H. \& Broman, G. (2017) A strategic approach to social sustainability - Part 1: exploring social system. Journal of Cleaner Production, 140, pp. 32-41. DOI: 10.1016/j.jclepro.2016.03.170

Mohit, M. A., Ibrahim, M. \& Rashid, Y. R. (2010) Assessment of residential satisfaction in newly designed public low-cost housing in Kuala Lumpur, Malaysia. Habitat International, 34(1), pp. 18-27.

DOI: 10.1016/j.habitatint.2009.04.002

Newman, O. (1972) Defensible space. New York, Macmillan.

Pain, R. (2000) Place, social relations and the fear of crime: A review. Progress in Human Geography, 24(3), pp. 365-387. DOI: 10.1191/030913200701540474

Parry, J., Vegeris, S., Hudson, M., Barnes, H. \& Taylor, R. (2004) Independ ent living in later life. Research Report No 216. Avilable at: http://campaigns.dwp.gov.uk/asd/asd5/rports2003-2004/rrep216.pdf (accessed 5. Sept. 2017).

Popov, Y. (2017) Relations between wellbeing and transport infrastructure of the country. Procedia Engineering, 178, pp. 579-588. DOI: 10.1016/j.proeng.2017.01.112

Ramovš, J. (2000) Medgeneracijska povezanost, samopomoč in kakovostna starost. Socialno delo, 39( 4-5), pp. 315-329.

Ravbar, M. (2007) Prostorsko planiranje - čemu? Geodetski vestnik, 51(2), pp. 233-245.

Roy, N., Bube, R., Despres, C., Freitas, A. \& Legare, F. (2018) Choosing between staying at home or moving: A systematic review of factors influencing housing decisions among frail older adults. PLoS One, 13(1), DOI: $10.1371 /$ journal.pone.0189266

Rojo, P., Fernandez-Mayoralas, G., Pozo Rivera, E. \& Manuel Rojo, A. (2001) Ageing in place: Predictors of the residential satisfaction of elderly. Social Indicators Research, 54(2), pp. 173-208. DOI: 10.1023/a:1010852607362

Sabia, J. (2008) There's no place like home: A hazard model analysis of aging in place among older homeowners in the PSID. Research on Aging, 30(1), pp. 3-35. DOI: 10.1177/0164027507307919

Sam, M., Fauzi, M. \& Saadatian, O. (2012) Residential satisfaction and construction. Journal of Scientific Research and Essays, 7(15), pp. 15561563.

Secker, J., Hill, R., Villeneau, L. \& Parkman, S. (2003) Promoting independence: But promoting what and how? Ageing and Society, 23, pp. 375-391. DOI: 10.1017/s0144686x03001193

Sendi, R. (2005) Sodelovanje stanovalcev kot pogoj za uspešno izvedbo prenove stanovanjskih sosesk. Urbani izziv, 16(2), pp. 5-15. DOI: 10.5379/urbani-izziv-2005-16-02-001

Sierra, L., Yepes, V. \& Pellicer, E. (2017) Assessing the social sustainability contribution of an infrastructure project under conditions of uncertainty. Environmental Impact Assessment Review, 67, pp. 61-72. DOI: 10.1016/j.eiar.2017.08.003
Sierra, L., Yepes, V. \& Pellicer, E. (2018) A review of multi-criteria assessment of the social sustainability of infrastructures. Journal of Cleaner Production, pp. 496-513. DOI: 10.1016/j.jclepro.2018.03.022

Sirgy, M. J. \& Cornwell, T. (2002) How neighborhood features affect quality of life. Social Indicators Research, 59, pp. 79-114.

Smrke, U., Blenkuš, M. \& Sočan, G. (2018): Residential satisfaction questionnaires: A systematic review. Urbani izziv, 29(2), pp. 67-82. DOI: 10.5379/urbani-izziv-en-2018-29-02-001

Strath, S., Isaacs, R. \& Greenwald, M. J. (2007) Operationalizing environmental indicators for physical activity in older adults. Journal of Aging and Physical Activity, 15(4), pp. 412-424. DOI: 10.1123/japa.15.4.412

Temeljotov Salaj, A., in Petrič, G. (2009): Nepremičninski dejavniki organizacijske klime. In: Brezovec, A. Mekinc, J. (eds.) Management, izobraževanje in turizem: kreativno v spremembe; Proceedings, pp. 2870 2879. Portorož, Turistica.

Theodori, G. L. (2001) Examining the effects of community satisfaction and attachment on individual well-being. Rural Sociology, 66(4), pp. 618-628. DOI: 10.1111/j.1549-0831.2001.tb00087.x

Trček, F. (2005) Socioloska anketna raziskava, Prenova stanovanjskih sosesk v Ljubljani -Savsko naselje. Urbani izziv, 2005, 16(2), pp. 24-35. DOI: 10.5379/urbani-izziv-2005-16-02-003

Uršič, M. (2005) Spreminjanje bivalne kakovosti in stanovanjska mobilnost v Ljubljani, Naraščanje socialne nestabilnosti v večjih stanovanjskih soseskah? Urbani izziv, 16(2), pp. 36-47. DOI: 10.5379/urbani-izziv-2005-16-02-004

Vaznonienè, G. (2015) The role of rural community enhancing rural social infrastructure changes. Research for rural development, 2, pp. 176182.

Vaznonienè, G. \& Pakeltienè, R. (2017) Methods for the assessment of rural social infrastructure needs. European Countryside, 9(3), pp. 526540. DOI: 10.1515/euco-2017-0031

Zapušek, A. \& Kučan, A. (2009) Stanovanjske krajine in kakovost bivanja. Predstavitev ukrepov za izboljšanje bivalne kakovosti, Annales, 19(1), pp. 1-18.

Weber, B., Alfen, H. W. \& Staub-Bisang, M. (2016) Infrastructure as an asset class-investment strategy, sustainability, project finance and PPP. Hoboken, NJ, John Wiley \& Sons. DOI: 10.1002/9781119226574

Wiles, L., Allena, R. E. S., Palmera, A., Haymana, K., Keelingb, S. \& Kersea, N. (2009): Older people and their social spaces: A study of well-being and attachment to place in Aotearoa New Zealand. Social Science \& Medicine, 68(4), pp. 664-671. DOI: 10.1016/j.socscimed.2008.11.030

Wylde, M. A. (2008) The future of assisted living. Residents' perspectives, 2006-2026. In: Golant S. M. Hyde J. (ed.) The assisted living residence. A vision for the future, pp. 169-197. Baltimore, MD, The Johns Hopkins University Press. 